\title{
Kidney ischemia and reperfunsion syndrome: effect of lidocaine and local postconditioning
}

\section{Síndrome de isquemia e reperfussão renal: efeito da lidocaína e do pós-condicionamento local}

Igor Nagal Yamaki, AsCbC-PA'; Ruy Victor Simöes Pontes'; Felipe lobato da Silva Costa²; Vitor Nagal Yamaki²; Renan Kleber Costa Teixeira ${ }^{3}$; Edson Yuzur Yasouma, tCBC-PA²; Marcus Vinicius Henriques Brito, TCBC-PA².

\section{A B S T R A C T}

\begin{abstract}
Objective: to evaluate the effects of blocking the regulation of vascular tone on the ischemia and reperfusion syndrome in rats through the use of lidocaine in the postconditioning technique. Methods: we randomized 35 rats into seven groups of five animals: Group 1- Control; Group 2- Ischemia and Reperfusion; Group 3-Ischemia, Reperfusion and Saline; Group 4- Ischemic Postconditioning; Group 5- Ischemic Postconditioning and Saline; Group 6- Lidocaine; Group 7- Ischemic Postconditioning and Lidocaine. Except for the control group, all the others were submitted to renal ischemia for 30 minutes. In postconditioning groups, we performed ischemia and reperfusion cycles of five minutes each, applied right after the main ischemia. In saline and lidocaine groups, we instilled the substances at a rate of two drops per minute. To compare the groups, we measured serum levels of urea and creatinine and also held renal histopathology. Results: The postconditioning and postconditioning + lidocaine groups showed a decrease in urea and creatinine values. The lidocaine group showed only a reduction in creatinine values. In histopathology, only the groups submitted to ischemic postconditioning had decreased degree of tubular necrosis. Conclusion: Lidocaine did not block the effects of postconditioning on renal ischemia reperfusion syndrome, and conferred better glomerular protection when applied in conjunction with ischemic postconditioning.
\end{abstract}

Keywords: Reperfusion Injury. Warm Ischemia. Reperfusion. Ischemic Postconditioning. Lidocaine. Rats.

\section{INTRODUCTION}

T he ischemia and reperfusion syndrome contributes to $60-70 \%$ of the morbidity and mortality related to the Cute Kidney Injury (AKI) present in various clinical situations, such as renal transplantation and renal artery embolism ${ }^{1-5}$. Although the immediate arterial blood reperfusion is the best approach to eliminate the ischemic process $^{6}$, cell reoxygenation is associated with an increase in lipid peroxidation, in cellular damage and in deterioration of the function 7,8

The recent description of "tissue conditioning" techniques, consisting of alternate cycles of brief ischemia and reperfusion, is a promising approach for controlling damage by prolonged ischemia and reperfusion injury ${ }^{6}$.

In 2003, Zhao et al. ${ }^{9}$ developed the concept of ischemic postconditioning (POS), which consists of small ischemia and reperfusion cycles before free reperfusion in a previously ischemic tissue. This technique can be easily applied in unexpected ischemias, especially when compared with preconditioning, with studies showing beneficial effects in humans ${ }^{10,11}$.

The mechanisms involved in the protective effect of POS against ischemia and reperfusion injury are poorly understood. It is known that this procedure works in modulation of mitochondrial potassium channels, the mitochondrial permeability transition pore and via p13-kinase-pAkt signaling ${ }^{12}$.

The exact POS intracellular mechanisms have not been fully determined. A mechanism suggested by some studies would be the vascular tone modulation ${ }^{13,14}$, wherein the postconditioning would increase the number and duration of contraction of the arterioles, preventing a large influx of oxygen and therefore the generation of reactive oxygen species. However, in the literature review, we identified no study directly assessing this route.

1 - Faculty of Medicine, Pará University Center (CESUPA), Belém, PA, Brazil. 2 - Faculty of Medicine, Pará State University (UEPA), Belém, PA, Brazil. 3 - Post-graduate Program in Surgery and Experimental Research, Pará State University (UEPA), Belém, PA, Brazil. 
Lidocaine is a local anesthetic, often used to perform minor surgical procedures. It acts by blocking sodium channels, preventing the nerve impulse and the painful feeling ${ }^{15,16}$. However, when administered systemically, it has a vasodilatory effect, which could be used to block the vascular tone modulation ${ }^{17}$.

Thus, this study aims to assess the effects of blocking the regulation of vascular tone in ischemia and reperfusion syndrome in rats, through the use of lidocaine in the ischemic postconditioning technique.

\section{METHODS}

We used thirty-five male Wistar rats (Rattus norvegicus) aged 15 to 20 weeks, weighing 250-300 g study. We kept the animals in a vivarium of the Experimental Surgery Laboratory of the Pará State University, in a controlled environment, with water and food offered ad libitum. This research followed the Brazilian law of animal experimentation $(11,794 / 08)$. The research project was approved by the Ethics in Research Committee of the Pará State University (43/12)

We randomly divided the animals into seven groups of five animals each: 1) Control group (CON), in which renal ischemia was not induced; 2) Group ischemia and reperfusion (IR), which underwent renal ischemia for 30 minutes followed by reperfusion without any conditioning technique; 3) Group ischemia and saline reperfusion (IRS), which underwent renal ischemia for 30 minutes followed by saline infusion in the renal artery at a rate of two drops per minute (Figure 1); 4) Ischemic postconditioning group (POS), subjected to 30 minutes of renal ischemia followed by 30 minutes of local postconditioning (three cycles of five minutes

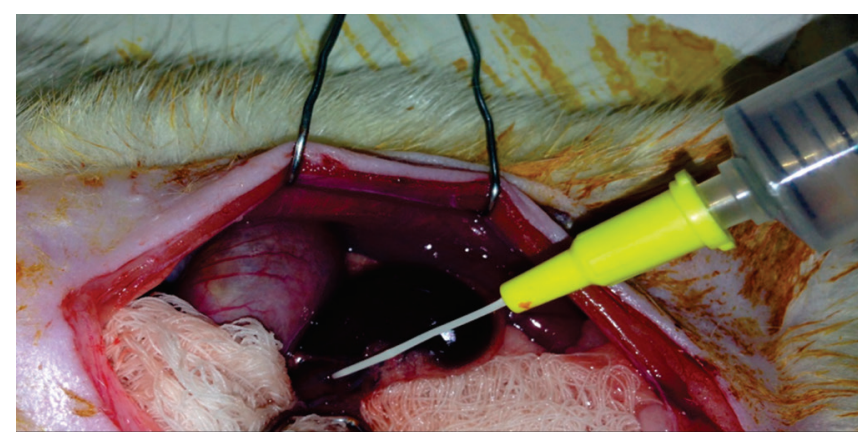

Figure 1. Technique of instillation in the left renal artery. of perfusion interspersed by five minutes of ischemia) ${ }^{13}$; 5) Ischemic postconditioning and saline group (POSS), submitted 30 minutes of renal ischemia followed by 30 minutes of the local postconditioning ( 3 cycles of 5 minutes of renal perfusion interspersed with five min of renal ischemia) $)^{11}$ and instillation of saline in the renal artery at a rate of two drops per minute; 6 ) Lidocaine group (LIDO), subjected to 30 minutes of renal ischemia followed by 30 minutes of lidocaine instillation into the renal artery at a rate of two drops per minute; 7) Postconditioning and lidocaine group (POLI), submitted 30 minutes of renal ischemia followed by 30 minutes of the local postconditioning and instillation of lidocaine in the renal artery.

We performed all procedures under anesthesia with ketamine $70 \mathrm{mg} / \mathrm{kg}$ and xylazine $10 \mathrm{mg} / \mathrm{kg}$ intraperitoneally. In all groups, we performed right nephrectomy and dissected the left renal artery with the aid of a microsurgical microscope. We induced renal ischemia by applying a microsurgical clamp on the left renal artery for 30 minutes. We maintained the temperature of the animals at $37^{\circ} \mathrm{C}$ using a thermal blanket throughout the procedure. We performed postoperative rehydration through saline injection $(10 \mathrm{ml} / \mathrm{kg})$ subcutaneously.

During the observation period, the animals received analgesia with dipyrone $30 \mathrm{mg} / \mathrm{kg}$ every eight hours and water and food ad libitum. The animals were individual in cages postoperatively. We evaluated the amount of food and water consumed before and after surgery.

Twenty-four hours after surgery, animals were again anesthetized. We obtained blood samples from the vena cava and immediately sent them to biochemical analysis. Serum urea and creatinine were measured using the colorimetric assay in a Selectra-E device using specific Labtest ${ }^{\circledR}$ kits. We removed the left kidney and fixed it in 10\% buffered formalin. The pieces were stained with hematoxylin and eosin. We analyzed the presence of tubular necrosis, medullary congestion and retraction of the glomerular tuft, graduating it as 0 - absent; 1 - mild; 2 - moderate; and 3 - intense. We euthanized the animals by anesthesia overdose. 
Table 1. Serum levels of urea and creatinine.

\begin{tabular}{|c|c|c|}
\hline Group & Urea (mg/dl) & Creatinine $(\mathrm{mg} / \mathrm{dl})$ \\
\hline CON & $39.40 \pm 3.43$ & $0.50 \pm 0.10$ \\
\hline IR & $216.30 \pm 2.52$ & $2.06 \pm 0.26$ \\
\hline IRS & $208.40 \pm 4.66$ & $2.11 \pm 0.19$ \\
\hline POS & $141.40 \pm 43.77$ & $0.93 \pm 0.18$ \\
\hline POSS & $140.20 \pm 30.98$ & $1.02 \pm 0.26$ \\
\hline LIDO & $187.80 \pm 53.73$ & $1.27 \pm 0.41$ \\
\hline POLI & $80.50 \pm 15.08$ & $0.76 \pm 0.08$ \\
\hline
\end{tabular}

$p<0.05$ CON vs other groups; $p>0.05$ IR and IRS vs POS, POSS and LIDO; $p>0.05$ vs IRS and POS vs POSS.

We expressed the results as mean \pm standard deviation. We used the BioEstat ${ }^{\circledR} 5.4$ software (Belém, PA, Brazil) for statistical analysis. We used the ANOVA test followed by Tukey's post-test to compare the levels of urea and creatinine between groups, and the Kruskal-Wallis test to compare the histopathological scores. We adopted a value less than 0.05 or $5 \%$ to reject the null hypothesis.

\section{RESULTS}

During the entire study period, no animal died or needed resuscitation maneuvers. There was no change in the feeding patterns of animals during pre and postoperative periods (18.63 g/day vs $17.44 \mathrm{~g} /$ day, $\mathrm{p}<0.05)$. We noticed that the IR group had higher urea levels that CON, POS and POLI groups $(p<0.01)$, showing no significant difference when compared with the LIDO group ( $p=0.62$ ). The POLI group achieved better serum levels than the POS group ( $p=0.045)$, and was the only group that showed urea levels similar to the CON group $(p=0.32)$.

With respect to creatinine, the IR group showed the highest levels when compared with all other groups $(p<0.001)$; the POLI group achieved better serum levels than the POS group ( $p=0.043)$ and was the only group that showed creatinine levels statistically similar to the CON group ( $p=0.57$ ). The LIDO group showed higher creatinine levels than POS and POLI groups $(p<0.01)$. Table 1 shows the serum levels of urea and creatinine per group.

Table 2 shows the results of the histopathological analysis. We identified a lesser degree of glomerular injury in all treated groups $(p<0.05)$, but only in the postconditioning groups there was a reduction in the level tubular injury $(p<0.05)$.

\section{DISCUSSION}

The exact mechanism of ischemic postconditioning is poorly understood. It is known that its effects are mediated through potassium channels ${ }^{16,18}$, modulated by neural and humoral mechanisms that critically depend on the time at which the conditioning is applied. When performed immediately after the main ischemia, the neuronal pathway is dominant, through a parasympathetic action ${ }^{19}$. However, when applied shortly after the main ischemia, the humoral mechanism is predominant, through the RISK and SAFE pathways ${ }^{8}$.

One of the parasympathetic actions is the regulation of vascular tone that, when activated, causes an increase in blood flow by vasodilatation ${ }^{20}$. The tone of the renal artery is regulated primarily by the sympathetic pathway, which promotes dilation when inhibited ${ }^{21}$. Our hypothesis with lidocaine instillation in the renal artery is that it should generate a parasympathetic effect through of the sympathetic-type blocking of the vascular tone, resulting in a sustained vasodilation with blocking of the postconditioning neurogenic pathway.

The blood markers of renal function were decreased in the group subjected to the postconditioning, as identified in several other studies. However, lidocaine-treated animals also showed a beneficial effect, 
Table 2. Average histopathological scores.

\begin{tabular}{lccccccc}
\hline \multicolumn{1}{c}{ Parameter } & CON & IR & IRS & POS & POSS & LIDO & POLI \\
\hline Tubular necrosis & 0.00 & 2.60 & 2.40 & 1.40 & 1.20 & 2.20 & 1.20 \\
Medullary congestion & 0.00 & 2.80 & 2.60 & 1.20 & 1.40 & 2.20 & 1.00 \\
Glomerular retraction & 0.00 & 2.40 & 2.60 & 1.40 & 1.00 & 1.40 & 1.20 \\
\hline
\end{tabular}

p<0.05 CON vs other groups; p>0.05 IR vs IRS and POS vs POSS. Tubular necrosis and Medullary Congestion: $p<0.05$ POS, POSS and POLI vs CON, IR, IRS and LIDO; Glomerular retraction: $p<0.05$ POS, POSS, POLI and LIDO vS CON, IR and IRS.

particularly in relation to creatinine, displaying an additional glomerular protection ${ }^{22}$. We did not observed this difference regarding urea levels, demonstrating a higher tubular compromise since, under normal conditions, the loop of Henle is responsible for $60 \%$ of urea urinary secretion $^{23}$.

It is important to note that the groups treated with saline had no effect similar to the lidocaine group, indicating that the reduction of markers was due to the pharmacological properties of lidocaine and not to a possible volume overload of the instilled lidocaine.

One possible mechanism involved in the lidocaine protective effect of is the blockade of NaV 1.9 channels, which are closely related to the pathophysiology of ischemia and reperfusion syndrome ${ }^{16}$. When this channel is blocked, there is a decrease in the intracellular influx of sodium and less reperfusion injury. However, Lee et al. ${ }^{24}$ demonstrated that the continuous infusion of lidocaine in rats' subcutaneous tissue had deleterious effects on the ischemia and reperfusion syndrome, suggesting that there is still need for greater understanding of this drug effects and the influence of the route of administration.
Histologically, no significant differences were evident when comparing the histological grade of glomerular and tubular injury, with results similar to those identified in the analysis of serum urea and creatinine and confirming the initial conclusions. We observed no further lesion by the use of lidocaine, which some studies proved to be toxic to the renal epithelium ${ }^{24,25}$.

Further studies are required before the clinical use of lidocaine, especially using other analysis parameters such as oxidative stress and cell viability, not tested in this initial work ${ }^{26}$. Furthermore, there is controversy in the literature on whether the ischemic postconditioning is influenced by the number of cycles or by the conditioning time $^{27}$. Five-minute cycles may not have been the appropriate model to determine the maximum protective effect on ischemia and reperfusion. Thus, if we had applied an ideal cycle, lidocaine solution could not have presented the described effects.

In conclusion, lidocaine did not block the postconditioning effects on the ischemia and reperfusion syndrome, but determined a better result in glomerular protection when applied in conjunction with this technique.

\section{R E S U M O}

Objetivo: avaliar os efeitos do bloqueio da regulação do tônus vascular por meio do uso da lidocaína na técnica de pós-condicionamento isquêmico na síndrome de isquemia e reperfusão renal em ratos. Métodos: trinta e cinco ratos foram randomizados em sete grupos de cinco animais: Grupo 1- Controle; Grupo 2- Isquemia e Reperfusão; Grupo 3- Isquemia, Reperfusão e Solução Salina; Grupo 4- Pós-condicionamento Isquêmico; Grupo 5- Pós-condicionamento Isquêmico e Solução Salina; Grupo 6- Lidocaína; Grupo 7- Pós-condicionamento Isquêmico e lidocaína. Com exceção do grupo controle, todos os demais foram submetidos à isquemia renal de 30 minutos. Nos grupos de pós-condicionamento, foi realizado o ciclo de isquemia e reperfusão de cinco minutos cada, aplicado logo após a isquemia principal. Nos grupos salina e lidocaína foram instiladas as substâncias numa taxa de duas gotas por minuto. Para comparar os grupos, foram dosados os níveis séricos de ureia e creatinina e análise histopatológica renal. Resultados: os grupos pós-condicionamento e pós-condicionamento + lidocaína apresentaram uma redução nos valores de ureia e creatinina. O grupo lidocaína apresentou apenas uma redução nos valores de creatinina. Na análise histopatológica, apenas os grupos submetidos ao pós-condicionamento isquêmico apresentaram redução do grau de necrose tubular. Conclusão: a lidocaína não bloqueou os efeitos do pós-condicionamento na síndrome de isquemia e reperfusão renal, mas conferiu melhor na proteção glomerular quando aplicada em conjunto com o pós-condicionamento isquêmico.

Descritores: Traumatismo Por Reperfusão. Isquemia Quente. Reperfusão. Pós-Condicionamento Isquêmico. Lidocaína. Ratos. 


\section{REFERENCES}

1. Yellon DM, Hausenloy DJ. Myocardial reperfusion injury. N Engl J Med. 2007;357(11):1121-35.

2. Nolan CR, Anderson RJ. Hospital-acquired acute renal failure. J Am Soc Nephrol. 1998; 9(4):710-8.

3. Ryan S, Taylor CT, McNicholas WT. Selective activation of inflammatory pathways by intermittent hypoxia in obstructive sleep apnea syndrome. Circulation. 2005;112(17):2660-7.

4. Eltzschig HK, Eckle T. Ischemia and reperfusion - from mechanism to translation. Nat Med. 2011;17(11):1391-401.

5. Castro e Silva Jr O, Centurion S, Pacheco EG, Brisotti $\mathrm{JL}$, Oliveira AF, Sasso KD. Basic aspects of the ischemia reperfusion injury and of the ischemic preconditioning. Acta Cir Bras. 2002;17 (Suppl 3): 96-100.

6. Vinten-Johansen J, Shi W. Perconditioning and postconditioning: current knowledge, knowledge gaps, barriers to adoption, and future directions. J Cardiovasc Pharmacol Ther. 2011;16(3-4):260-6.

7. Piper HM, Garcia-Dorado D, Ovize M. A fresh look at reperfusion injury. Cardiovasc Res. 1998;38(2):291-300.

8. Tamareille S, Mateus V, Ghaboura N, Jeanneteau J, Croué A, Henrion D, et al. RISK and SAFE signaling pathway interactions in remote limb ischemic perconditiong in combination with local ischemic postconditioning. Basic Res Cardiol. 2011;106(6):1329-39.

9. Zhao ZQ, Corvera JS, Halkos ME, Kerendi F, Wang NP, Guyton RA, et al. Inhibition of myocardial injury by ischemic postconditioning during reperfusion: comparison with ischemic preconditioning. Am J Physiol Heart Circ Physiol. 2003;285(2):H579-88.

10. Venugopal V, Laing CM, Ludman A, Yellon DM, Hausenloy D. Effect of remote ischemic preconditioning on acute kidney injury in nondiabetic patients undergoing coronary artery bypass graft surgery: a secondary analysis of 2 small randomized trials. Am J Kidney Dis. 2010;56(6):1043-9.

11. Er F, Nia AM, Dopp H, Hellmich M, Dahlem KM, Caglayan $\mathrm{E}$, et al. Ischemic preconditioning for prevention of contrast medium-induced nephropathy: randomized pilot RenPro Trial (Renal Protection Trial).
Circulation. 2012; 126(3):296-303.

12. Dow J, Bhandari A, Kloner RA. The mechanism by which ischemic postconditioning reduces reperfusion arrhythmias in rats remains elusive. J Cardiovasc Pharmacol Ther. 2009;14(2):99-103.

13. Costa FL, Yamaki VN, Goncalves TB, Coelho JV, Percário $\mathrm{S}$, Brito MV. Combined remote ischemic perconditioning and local postconditioning on liver ischemia-reperfusion injury. J Surg Res. 2014;192(1):98-102.

14. Hedegaard ER, Johnsen J, Povlsen JA, Jespersen NR, Shanmuganathan JA, Laursen MR, et al. Inhibition of KV7 channels protects the rat heart against myocardial ischemia and reperfusion injury. J Pharmacol Exp Ther. 2016; 357(1):94-102.

15. Gawali VS, Lukacs P, Cervenka R, Koenig X, Rubi L, Hilber $K$, et al. Mechanism of modification, by lidocaine, of fast and slow recovery from inactivation of Voltage-Gated $\mathrm{Na} \square$ Channels. Mol Pharmacol. 2015;88(5):866-79.

16. Dusmez D, Cengiz B, Yumrutas O, Demir T, Oztuzcu $S$, Demiryurek $S$, et al. Effect of verapamil and lidocaine on TRPM and NaV1.9 gene expressions in renal ischemia-reperfusion. Transplant Proc. 2014;46(1):33-9.

17. Kawahito S, Nakahata K, Azma T, Kuroda Y, Cook DJ, Kinoshita H. Protective effects of anesthetics on vascular function related to $\mathrm{K} \square$ channels. Curr Pharm Des. 2014;20(36):5727-37.

18. Basalay M, Barsukevich V, Mastitskaya S, Mrochek A, Pernow J, Sjöquist PO, et al. Remote ischaemic pre- and delayed postconditioning - similar degree of cardioprotection but distinct mechanisms. Exp Physiol. 2012;97(8):908-17.

19. Donato $M$, Buchholz $B$, Rodríguez $M$, Pérez $V$, Inserte J, García-Dorado D, et al. Role of the parasympathetic nervous system in cardioprotection by remote hindlimb ischaemic preconditioning. Exp Physiol. 2013;98(2):425-34.

20. Schiller AM, Haack KK, Pellegrino PR, Curry PL, Zucker $\mathrm{IH}$. Unilateral renal denervation improves autonomic balance in conscious rabbit with chronic heart failure. Am J Physiol Regul Integr Comp Physiol. 2013;305(8):886-92. 
21. DiBona GF. Neural control of renal function: role of renal alpha adrenoreceptors. J Cardiovasc Pharmacol. 1985;7 Suppl 8:S18-23.

22. Passos MT, Nishida SK, Câmara NO, Shimizu $\mathrm{MH}$, Mastroianni-Kirsztajn G. Lohexol clearance for determination of glomerular filtration rate in rats induced to acute renal failure. Plos One. 2015;10(4):e0123753.

23. Pagana KD, Pagana TJ. Urea nitrogen, Blood. In: Pagana KD, Pagana TJ, editors. Mosby’s diagnostic \& laboratory test reference. 11 th ed. St. Louis: Mosby; 2011. p. 131-3.

24. Lee HT, Krichevsky IE, Xu H, Ota-Setlik A, D'Agati VD, Emala CW. Local anesthetics worsen renal function after ischemia-reperfusion injury in rats. Am J Physiol Renal Physiol. 2004;286(1):F111-9.

25. Drewa TA, Wolski Z, Galazka P, Wlodarczyk Z, Wozniak A. Kidney preserving solutions containing lidocaine may increase urological complication rate after renal transplantation: an in vitro study. Transplant Proc. 2005;37(5): 2107-10.

26. Costa FL, Teixeira RK, Yamaki VN, Valente AL, Silva $\mathrm{AM}$, Brito MV, et al. Remote ischemic conditioning temporarily improves antioxidant defense. J Surg Res. 2016;200(1):105-9.

27. Chen $H$, Xing B, Liu X, Zhan B, Zhou J, Zhu H, et al. Ischemic postconditioning inhibits apoptosis after renal ischemia/reperfusion injury in rat. Transpl Int. 2008;21(4):364-71.

Received in: 06/04/2016

Accepted for publication: 01/09/2016

Conflict of interest: none.

Source of funding: none.

Mailing address:

Renan Kleber Costa Teixeira

E-mail: renankleberc@hotmail.com 